Int. J. Dev. Biol. 56: 789-797 (2012)

doi: $10.1387 / \mathrm{ijdb} .120230 \mathrm{ja}$

\title{
Comparative molecular portraits of human unfertilized oocytes and primordial germ cells at 10 weeks of gestation
}

\author{
FERDINAND DIEDRICHS ${ }^{1}$, BARBARA MLODY ${ }^{1}$, PEGGY MATZ1, HEIKO FUCHS ${ }^{1,2}$, LUKAS CHAVEZ', \\ KATHARINA DREWS ${ }^{1}$ and JAMES ADJAYE*,1,2 \\ ${ }^{1}$ Department of Vertebrate Genomics, Molecular Embryology and Aging Group, Max Planck Institute for Molecular \\ Genetics, Berlin, Germany and ${ }^{2}$ Institute for Stem Cell Research and Regenerative Medicine, Medical Faculty, \\ Heinrich Heine University Duesseldorf, Duesseldorf, Germany
}

\begin{abstract}
Primordial germ cells (PGCs) are precursors of gametes and share several features in common with pluripotent stem cells, such as alkaline phosphatase activity and the expression of pluripotency-associated genes such as OCT4 and NANOG. PGCs are able to differentiate into oocytes and spermatogonia and establish totipotency after fertilization. However, our knowledge of human germ cell development is still fragmentary. In this study, we have carried out genomewide comparisons of the transcriptomes and molecular portraits of human male PGCs (mPGCs), female PGCs (fPGCs) and unfertilized oocytes. We detected 9210 genes showing elevated expression in fPGCs, 9184 in mPGCs and 9207 in oocytes, with 6342 of these expressed in common. As well as known germ cell-related genes such as BLIMP1/PRDM1, PIWIL2, VASA/DDX4, DAZL, STELLA/ DPPA3 and LIN28, we also identified 465 novel non-annotated genes with orthologs in the mouse. A plethora of olfactory receptor-encoding genes were detected in all samples, which would suggest their involvement not only in sperm chemotaxis, but also in the development of female germ cells and oocytes. We anticipate that our data might increase our meagre knowledge of the genes and associated signaling pathways operative during germ cell development. This in turn might aid in the development of strategies enabling better differentiation and molecular characterisation of germ cells derived from either embryonic or induced pluripotent stem cells. Ultimately, this would have a profound relevance for reproductive as well as regenerative medicine.
\end{abstract}

KEY WORDS: $P G C$, oocyte, transcriptome, signaling pathway, meiosis, olfactory receptor

\section{Introduction}

Primordial germ cells (PGCs) are the embryonic precursors of gametes. They could be regarded as the mother of all stem cells because of their unique ability to retain true developmental totipotency. But despite many similarities with embryonic stem cells (ESCs), they exhibit only temporary self-renewal capability and have distinct lineage-specific characteristics. In fact, under normal conditions, PGCs are believed to differentiate into germ cells only, which are oocytes in the female and prospermatogonia in the male, to ultimately produce eggs and sperm, respectively. It is not until the fertilization of the egg that the intrinsic germ cell program for totipotency is established.
Although restricted in developmental potency, PGCs share several molecular characteristics of pluripotent cells, these include high alkaline phosphatase activity (Ginsburg et al., 1990; Goto et al., 1999), expression of key pluripotency-related genes such as POU5F1/OCT4, NANOG and ESG1 (Goto et al., 1999; Western et al., 2005; Sabour et al., 2011). In addition, PGCs can give rise to embryonal carcinoma (EC) cells, the stem cells of testicular tumors, in vivo. Besides, when cultured under stimulation with

Abbreviations used in this paper: dpc, days post coitum; EC cells, embryonal carcinoma cells; EG cells, embryonic germ cells; ESCs, embryonic stem cells; iPSCs, induced pluripotent stem cells; mPGC/fPGC, male/female primordial germ cell; Oocs, oocytes; OR, olfactory receptor; rep, replicate.

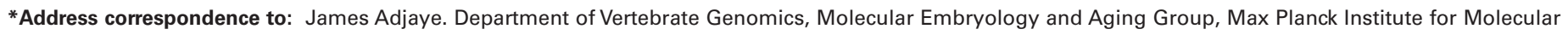
Genetics, Ihnestrasse 63-73, D-14195 Berlin, Germany. Tel: +49-211-81-08191. Fax: +49-211-81-19147.

e-mail: adjaye@molgen.mpg.de; James.Adjaye@med.uni-duesseldorf.de - web: http://www.molgen.mpg.de/ molemb

http://www.uniklinik-duesseldorf.de/unternehmen/institute/institut-fuer-stammzellforschung-und-regenerative-medizin/research
}

Supplementary Material (one figure +5 tables) for this paper is available at: http://dx.doi.org/10.1387/ijdb.120230ja

Final, author-corrected PDF published online: 5 February 2013.

ISSN: Online 1696-3547, Print 0214-6282 
specific growth factors, PGCs can be converted into pluripotent embryonic germ (EG) cells. However, unlike EC and EG cells, PGCs cannot be cultured indefinitely, do not form embryoid bodies in culture and when injected into a host blastocyst cannot populate either the soma or the germline (Donovan and de Miguel, 2003).

PGCs are difficult to study because they are limited in number, deeply embedded within the embryo, and are known to migrate during development (Ginsburg et al., 1990; McLaren and Southee, 1997), which limits the number of effective studies using these cells. Previous studies have demonstrated that around day 7 post coitum (dpc) in mice, PGCs can be detected at the base of the allantois within extraembryonic mesoderm. There, PGCs develop as a cluster of $40-50$ cells. At $10 \mathrm{dpc}$ the PGCs migrate to the genital ridge (Ginsburg et al., 1990; Goto et al., 1999; Anderson et al., 2000; Molyneaux et al., 2001; Saitou et al., 2002), the sex determination starts and ends around $13 \mathrm{dpc}$. Female germ cells start entering meiosis, in contrast to male germ cells which pause at the mitotic stage and start meiosis at day 10 after birth (Ewing et al., 1993).

In human, PGCs are identified in the hind gut at 4 weeks of gestation and then migrate to colonize the developing gonads by 7 weeks of gestation (Witschi, 1946; Gondos and Hobel, 1971; Motta and Makabe, 1986). At 10 weeks of gestation, female PGCs (fPGCs) start to enter meiosis, while male PGCs (mPGCs) continue to divide mitotically until they are arrested in mitosis at 16-18 weeks of gestation (Gondos and Hobel, 1971; Goto et al., 1999).

Many factors control the migration, proliferation and organisation of PGCs to developing gonads as well as the integration of somatic cells surrounding the PGCs. Bone morphogenetic proteins (BMPs) regulate gene expression and formation of PGCs (Ying et al., 2000; Ying and Zhao, 2001; Pesce et al., 2002). Recent successful studies have demonstrated that PGCs can be derived from pluripotent stem cells in vitro, these can then be further differentiated into oocyte-like cells or spermatogenic-like cells (Hubner et al., 2003; Toyooka et al., 2003; Geijsen et al., 2004; Kee et al., 2006; Nagano, 2007; Qing et al., 2007; Wei et al., 2008; Panula et al., 2011).

Based on the complex control system during migration, proliferation and development of PGCs into gonads many disorders can arise if this developmental program is skewed. For example, different types of germ-cell tumors (GCTs) can result from mis-regulated expression of key PGCs-related genes. GCTs are a heterogeneous
TABLE 1

\section{CANONICAL PATHWAYS ENRICHED IN FEMALE PGC AND OOCYTE TRANSCRIPTOMES}

\begin{tabular}{|c|c|c|c|c|}
\hline \multirow[b]{2}{*}{ IPA Canonical Pathways } & \multicolumn{2}{|c|}{ fPGCs } & \multicolumn{2}{|c|}{ Oocs } \\
\hline & p-value & Ratio & p-value & Ratio \\
\hline EIF2 Signaling & $3.98 \mathrm{E}-17$ & $68 \%$ & $5.01 \mathrm{E}-13$ & $64 \%$ \\
\hline Regulation of elF4 and p70S6K Signaling & $2.51 \mathrm{E}-14$ & $63 \%$ & $1.58 \mathrm{E}-11$ & $60 \%$ \\
\hline mTOR Signaling & $7.94 \mathrm{E}-11$ & $60 \%$ & $4.90 \mathrm{E}-10$ & $59 \%$ \\
\hline ILK Signaling & $1.74 \mathrm{E}-06$ & $58 \%$ & $4.90 \mathrm{E}-05$ & $56 \%$ \\
\hline Mitochondrial Dysfunction & 3.31E-05 & $47 \%$ & 7.08E-06 & $48 \%$ \\
\hline Ephrin Receptor Signaling & 3.39E-05 & $51 \%$ & 4.47E-07 & $54 \%$ \\
\hline Huntington's Disease Signaling & 3.72E-05 & $52 \%$ & 6.61E-05 & $52 \%$ \\
\hline Wnt/ $\beta$-catenin Signaling & $6.31 \mathrm{E}-05$ & $57 \%$ & 3.31E-05 & $58 \%$ \\
\hline Aminoacyl-tRNA Biosynthesis & $1.07 \mathrm{E}-06$ & $37 \%$ & 2.04E-03 & $30 \%$ \\
\hline PI3K/AKT Signaling & 3.16E-06 & $55 \%$ & $1.70 \mathrm{E}-04$ & $51 \%$ \\
\hline Pyrimidine Metabolism & 8.13E-06 & $40 \%$ & $1.45 \mathrm{E}-04$ & $38 \%$ \\
\hline Clathrin-mediated Endocytosis Signaling & $9.77 \mathrm{E}-06$ & $56 \%$ & $1.70 \mathrm{E}-03$ & $51 \%$ \\
\hline Cell Cycle Regulation by BTG Family Proteins & $1.05 \mathrm{E}-05$ & $78 \%$ & $2.29 \mathrm{E}-03$ & $67 \%$ \\
\hline Protein Ubiquitination Pathway & $1.55 \mathrm{E}-05$ & $54 \%$ & 2.04E-04 & $52 \%$ \\
\hline Role of CHK Proteins in Cell Cycle Checkpoint Control & $1.62 \mathrm{E}-05$ & $70 \%$ & 1.35E-02 & $57 \%$ \\
\hline Cyclins and Cell Cycle Regulation & 2.69E-05 & $59 \%$ & $1.74 \mathrm{E}-04$ & $57 \%$ \\
\hline Oxidative Phosphorylation & 7.59E-05 & $54 \%$ & 2.75E-04 & $52 \%$ \\
\hline Role of BRCA1 in DNA Damage Response & 8.13E-05 & $63 \%$ & $1.22 \mathrm{E}-01$ & $48 \%$ \\
\hline AMPK Signaling & 9.77E-05 & $48 \%$ & $3.72 \mathrm{E}-04$ & $46 \%$ \\
\hline Integrin Signaling & $1.55 \mathrm{E}-04$ & $53 \%$ & $1.00 \mathrm{E}-06$ & $57 \%$ \\
\hline Axonal Guidance Signaling & $1.12 \mathrm{E}-04$ & $48 \%$ & $3.24 \mathrm{E}-06$ & $50 \%$ \\
\hline Germ Cell-Sertoli Cell Junction Signaling & 1.17E-03 & $53 \%$ & 3.47E-06 & $58 \%$ \\
\hline Signaling by Rho Family GTPases & 1.20E-03 & $49 \%$ & 6.31E-06 & $53 \%$ \\
\hline Rac Signaling & $1.62 \mathrm{E}-03$ & $49 \%$ & 7.24E-06 & $55 \%$ \\
\hline CDK5 Signaling & $1.48 \mathrm{E}-03$ & $\mathbf{5 5 \%}$ & $9.55 \mathrm{E}-06$ & $62 \%$ \\
\hline Molecular Mechanisms of Cancer & $8.51 \mathrm{E}-04$ & $47 \%$ & $1.12 \mathrm{E}-05$ & $49 \%$ \\
\hline Mitotic Roles of Polo-Like Kinase & $1.62 \mathrm{E}-03$ & $59 \%$ & 1.35E-05 & $67 \%$ \\
\hline ERK/MAPK Signaling & 6.17E-04 & $50 \%$ & 1.86E-05 & $53 \%$ \\
\hline Actin Cytoskeleton Signaling & $3.24 \mathrm{E}-03$ & $47 \%$ & 2.09E-05 & $52 \%$ \\
\hline RhoGDI Signaling & $2.88 \mathrm{E}-03$ & $47 \%$ & 3.39E-05 & $51 \%$ \\
\hline Ephrin B Signaling & 2.63E-03 & $55 \%$ & 3.47E-05 & $61 \%$ \\
\hline Breast Cancer Regulation by Stathmin 1 & $1.58 \mathrm{E}-03$ & $50 \%$ & 3.63E-05 & $53 \%$ \\
\hline IL-8 Signaling & $2.14 \mathrm{E}-03$ & $49 \%$ & 4.79E-05 & $52 \%$ \\
\hline
\end{tabular}

Summary of canonical pathways significantly enriched ( $p<0.0001$, highlighted in red (fPGCs) or green (oocytes)) in the set of genes expressed in PPGCs (9210) and oocytes (9207) as determined by IPA. The ratio describes the number of transcripts expressed in each data set that map to the pathway divided by the total number of genes that exist in the canonical pathway. To point out an additional level of enrichment bold numbers highlight differences between the fPGCs- or oocytes-specific ratios greater than or equal to $5 \%$. The entire IPA output, including corresponding $\mathrm{p}$-values and gene lists, is given in Supplementary Table 3.

group of neoplasms and are classified into five groups (I-V). They arise in ovaries and testes as well as in different extragonadal regions (Oosterhuis and Looijenga, 2005; Looijenga, 2009).

In this study, we aim at deriving molecular portraits of human unfertilized oocytes, male and female PGCs using mRNAs previously isolated in earlier studies (Adjaye et al., 1999; Goto et al., 1999; Adjaye and Monk, 2000). We anticipate that this data will form the
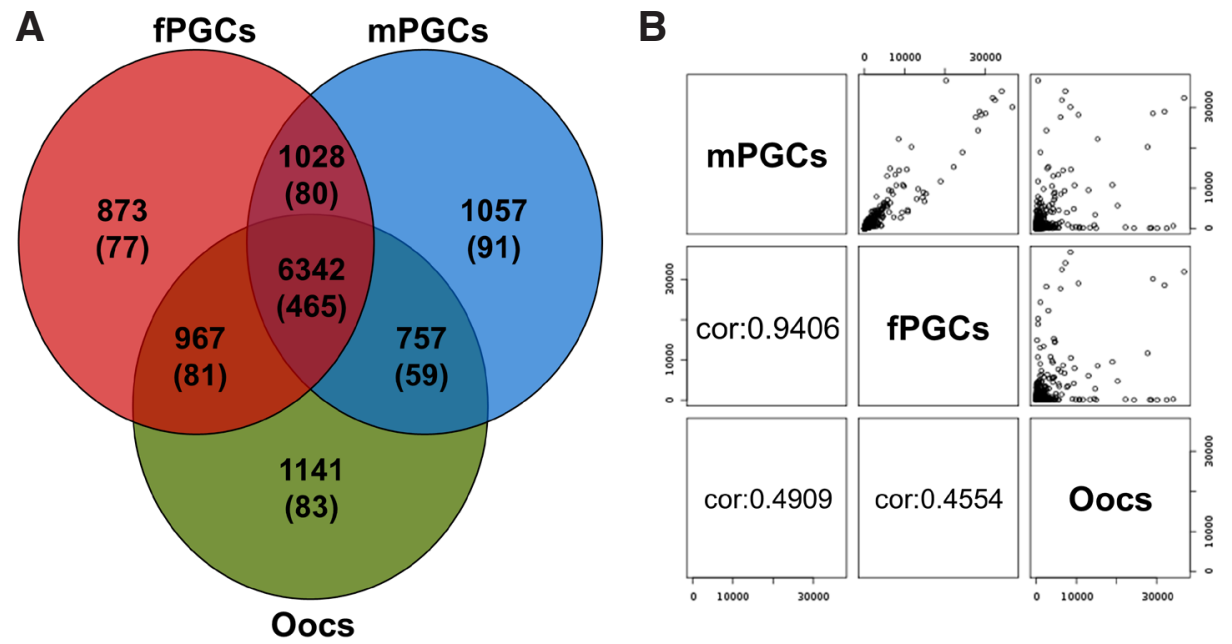

Fig. 1. Venn diagram-based analysis and correlation of the transcriptome of female PGCs, male PGCs and oocytes. (A) The Venn diagram depicts the overlaps of genes with elevated expression levels in fPGCs, MPGCs and oocytes as determined by microarray-based transcriptome profiling. The numbers in brackets represent the number of "novel" genes in each section which have not been functionally annotated to date, including, e.g. "LOC389936," "C12orf12," "FAM10A6,"'FLJ31568,"'KIAA0895L"'"MGC35361." (B) Scatter plots depicting the correlation of complete gene expression data sets of MPGCs, fPGCs and oocytes. Raw data were normalized by quantile normalization and Pearson correlation coefficients (cor) calculated between the different samples. 
A

A GO:0007600 sensory perception G0.0007606 $0050877 \sim$ neurological system process G0.0007608 sensory perception of sme $\frac{n}{m}$ Go:0007186 G-protein coupled receptor protein signaling pathway GO:0006952 defense response GO:0006968 cellular defense response GO:0042592 homeostatic process GO:0042063 gliogenesis

GO:0048878 chemical homeostasis GO-0010647 positive regulation of cell communication G0:0009967 positive regulation of signal transduction GO:0010524 positive regulation of calcium ion transport into cytosol 05
$\frac{u}{2}[$ GO:0005576 extracellular region GO:0005886 plasma membrane GO:0005615 extracellular space GO:0044421 extracellular region part GO:0031224 intrinsic to membrane GO:0016021 integral to membrane GO:0004984 olfactory receptor activity GO:0016502 14 purinergic nucleotide receptor activity GO:0001786 phosphatidylserine binding

B GO:0030001 metal ion transport
GO:0006812 cation transport
GO:0007267 cell-cell signaling GO:0007166 cell surface rece GO:0006814 sodium ion transport GO:0007626 locomotory behavior GO:0006811 ion transport GO:0015672 monovalent inorganic cation transport GO:0048871 multicellular organismal homeostasis GO:0010035 response to inorganic substance GO:0007186 G-protein coupled receptor prote in signaling pathway GO:0046903 secretion GO:0045321 leukocyte activation G0:0042108 positive regulation of cytokine biosynthetic process GO:0030595 leukocyte chemotaxis GO:0042035 regulation of cytokine biosynthetic process GO:0005886 plasma membrane GO:0044459 plasma membrane part GO:0031226 intrinsic to plasma membrane GO:0005887 integral to plasma membrane GO:0031224 intrinsic to membrane GO:0016021 integral to membrane GO:0001917 photoreceptor inner segment GO:0042995 cell projection GO:0046982 protein heterodimerization activity GO:0042802 identical protein binding GO:0046983 protein dimerization activity GO:0005261 cation channel activity GO:0046873 metal ion transmembrane transporter activity GO:0015267 channel activity GO:0022803 passive transmembrane transporter activity GO:0016494 C-X-C chemokine receptor activity GO:0004950 chemokine receptor activity GO:0031420 alkali metal ion binding GO:0016493 C-C chemokine receptor activity GO:0019957 C-C chemokine binding GO:0004687 myosin light chain kinase activity GO:0019958 C-X-C chemokine binding GO:0019956 chemokine binding

GO:0042803 protein homodimerization activity GO:0005216 ion channel activity GO:0005509 calcium ion binding GO:0031402 sodium ion binding

C $\left[\begin{array}{r}\text { GO:0051276 chromosome organization } \\ \text { GO:0030522 intracellular receptor-mediated signaling pathway }\end{array}\right.$ GO:0045449 regulation of transcription

GO:0006325 chromatin organization GO0030518 steroid hormone receptor signaling pathway GO:0010564 regulation of cell cycle process GO:0006350 transcription GO:0048562 embryonic organ morphogenesis GO:0044440 endosomal part GO:0010008 endosome membrane GO:0016841 ammonia-lyase activity GO:0030528 transcription regulator activity GO:0050681 androgen receptor binding GO:0003713 transcription coactivator activity GO:0003712 transcription cofactor activity GO:0003700 transcription factor activity
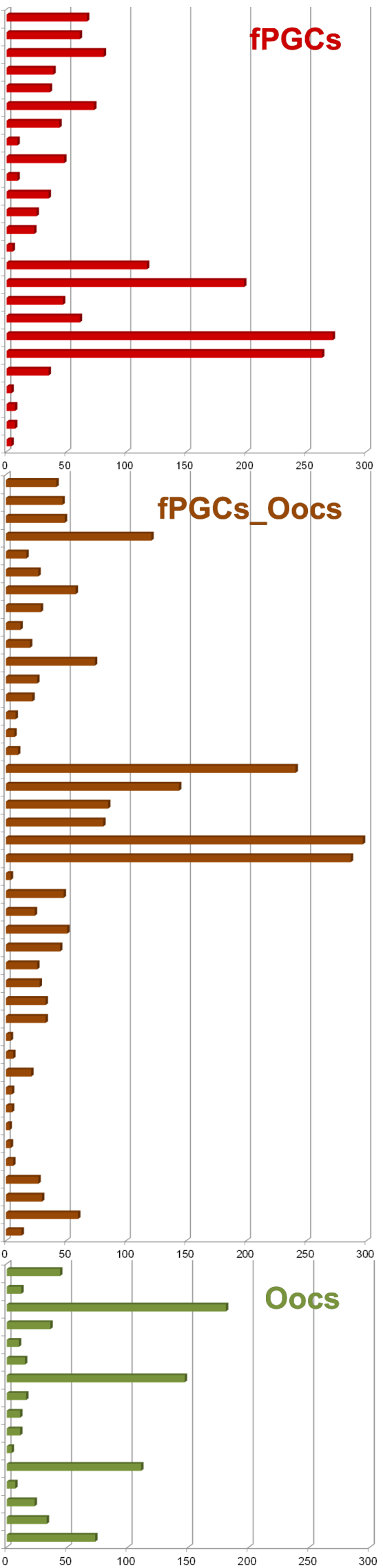

foundation for more extensive functional studies that might increase our meagre knowledge of the genes and associated pathways operative in these cells. This knowledge should also aid in our understanding of the aetiology of female germ cell derived cancers.

\section{Results}

\section{Global gene expression analysis}

Our aim was to profile and further analyse the transcriptomes and molecular portraits of distinct cell types of the female germ line, i.e. fPGCs and oocytes, using a microarraybased approach. We included mPGCs in the analyses to enable on the identification of genes specifically expressed in fPGCs and oocytes, i.e. female germ line-specific genes, in contrast to mPGCs-specific genes. Using our cut-off threshold, we detected 9210 genes showing elevated expression in fPGCs, 9207 genes for the oocytes sample and 9184 genes for the $\mathrm{mPGCs}$ as depicted in Fig. 1A. The majority of the 6342 germ cell-related genes, which includes housekeeping genes, are expressed in common between fPGCs, oocytes and mPGCs. Not surprisingly there are more genes in the overlap of fPGCs and mPGCs (1028) than in fPGCs and oocytes (967), or mPGCs and oocytes (757). Accordingly, the correlation coefficient between mPGCs and PPGCs is very high (0.94), whereas that between the PGCs and the oocytes are much lower (0.46 and 0.49 , respectively, Fig. 1B).

As expected we have identified several non-annotated genes (depicted as "LOC...", "C12orf...", "FAM...", "FLJ...", "KIAA..." and "MGC...") which we can assume as novel. This again highlights the novelty and usefulness of this study.

\section{Functional annotation and enrichment analysis of putative female germ line- specific genes}

As part of the DAVID functional annotation

Fig. 2. DAVID analysis of female PGC- and oocyte-specific genes. As shown in Fig. 1, all genes exclusively expressed in either fPGCs $(873, A)$ or oocytes $(1141, C)$ or overlapping between fPGCs and oocytes $(967, B)$ were assessed for functional enrichment of biological pathway-associated GOs $(B P)$, cellular component-associated GOs (CC) and molecular function-associated GOs (MF) using the DAVID database. Significantly enriched terms $(p<$ $0.01)$ are depicted. The terms are ordered by increasing $p$-values from top to bottom. The bars represent the number of genes that mapped to each term. The entire DAVID output, including corresponding $p$-values and gene lists, is given in Supplementary Table 2. 
TABLE 2

\section{BIOLOGICAL FUNCTIONS ENRICHED IN FEMALE PGC AND OOCYTE TRANSCRIPTOMES}

\begin{tabular}{|c|c|c|}
\hline Cancer & fPGCs p-value & Oocs p-value \\
\hline tumorigenesis & $6.72 \mathrm{E}-18$ & $7.22 \mathrm{E}-17$ \\
\hline neoplasia & $7.48 \mathrm{E}-15$ & 1.15E-13 \\
\hline cancer & $1.29 \mathrm{E}-14$ & $3.36 \mathrm{E}-13$ \\
\hline solid tumor & $2.31 \mathrm{E}-11$ & $1.36 \mathrm{E}-10$ \\
\hline carcinoma & 4.10E-11 & 4.99E-10 \\
\hline infection of tumor cell lines & 3.36E-07 & 3.82E-08 \\
\hline infection of cervical cancer cell lines & 4.30E-07 & 7.17E-10 \\
\hline cell transformation & $7.28 \mathrm{E}-07$ & 2.54E-08 \\
\hline mammary tumor & 2.40E-06 & 9.87E-06 \\
\hline colon tumor & 2.63E-06 & 2.63E-06 \\
\hline colon cancer & $6.54 \mathrm{E}-06$ & 4.26E-06 \\
\hline gastrointestinal tract cancer & 1.13E-05 & 7.93E-05 \\
\hline colorectal cancer & $1.24 \mathrm{E}-05$ & 2.13E-05 \\
\hline colorectal tumor & $8.40 E-06$ & 1.33E-04 \\
\hline intestinal cancer & $9.14 \mathrm{E}-06$ & 7.93E-05 \\
\hline hematological neoplasia & 3.10E-05 & $2.20 \mathrm{E}-03$ \\
\hline benign tumor & 5.46E-05 & $2.25 \mathrm{E}-03$ \\
\hline \multicolumn{3}{|l|}{ Cell Cycle } \\
\hline cell cycle progression & 4.38E-09 & $7.46 \mathrm{E}-15$ \\
\hline M phase & 5.81E-08 & $1.56 \mathrm{E}-10$ \\
\hline mitosis & 1.17E-05 & 8.78E-12 \\
\hline cytokinesis & $1.56 \mathrm{E}-05$ & 8.78E-08 \\
\hline interphase & 8.87E-05 & $2.88 \mathrm{E}-08$ \\
\hline modification of chromatin & 2.11E-03 & $2.40 \mathrm{E}-07$ \\
\hline remodeling of chromatin & \#N/A & 7.05E-06 \\
\hline senescence of cells & $1.28 \mathrm{E}-03$ & $1.40 \mathrm{E}-05$ \\
\hline G2/M phase & \#N/A & 2.53E-05 \\
\hline G2 phase & $1.74 \mathrm{E}-03$ & 3.63E-05 \\
\hline ploidy of cells & 4.08E-03 & 6.63E-05 \\
\hline arrest in interphase & 1.97E-03 & 8.19E-05 \\
\hline metaphase & \#N/A & 8.36E-05 \\
\hline aneuploidy of cells & $2.29 \mathrm{E}-03$ & $9.12 \mathrm{E}-05$ \\
\hline segregation of chromosomes & 2.17E-04 & $9.31 \mathrm{E}-05$ \\
\hline \multicolumn{3}{|l|}{ Cell Death } \\
\hline cell death & 3.59E-22 & $2.08 \mathrm{E}-24$ \\
\hline apoptosis & $5.60 \mathrm{E}-16$ & $2.59 \mathrm{E}-17$ \\
\hline necrosis & $1.11 \mathrm{E}-13$ & $9.63 E-13$ \\
\hline cell death of tumor cell lines & $6.55 \mathrm{E}-09$ & 3.42E-09 \\
\hline apoptosis of tumor cell lines & $9.86 \mathrm{E}-07$ & 1.21E-05 \\
\hline cell survival & 1.09E-06 & $1.52 E-05$ \\
\hline neuronal cell death & $1.49 \mathrm{E}-06$ & 4.76E-05 \\
\hline cell death of connective tissue cells & 2.85E-06 & 4.17E-06 \\
\hline cell viability & 3.10E-06 & $1.72 \mathrm{E}-04$ \\
\hline fragmentation of DNA & 2.45E-05 & $1.41 \mathrm{E}-03$ \\
\hline cell viability of tumor cell lines & $7.70 \mathrm{E}-05$ & \#N/A \\
\hline cell death of epithelial cells & $9.88 \mathrm{E}-05$ & $2.28 \mathrm{E}-03$ \\
\hline cell death of cervical cancer cell lines & 4.56E-03 & $3.59 \mathrm{E}-06$ \\
\hline \multicolumn{3}{|l|}{ Cellular Movement / Interaction } \\
\hline cytokinesis & $1.56 \mathrm{E}-05$ & 8.78E-08 \\
\hline binding of cells & 6.73E-05 & $\# \mathrm{~N} / \mathrm{A}$ \\
\hline cell movement & 1.14E-04 & 8.86E-06 \\
\hline cell movement of tumor cell lines & 5.52E-04 & 3.85E-05 \\
\hline \multicolumn{3}{|l|}{ Development / Morphology } \\
\hline morphology of reproductive system & 8.82E-07 & 1.31E-05 \\
\hline abnormal morphology of embryonic tissue & $1.75 \mathrm{E}-06$ & 1.19E-05 \\
\hline morphology of embryonic tissue & 2.36E-06 & 4.99E-06 \\
\hline size of embryo & $5.98 \mathrm{E}-06$ & 2.23E-09 \\
\hline proliferation of tumor cell lines & 4.15E-05 & 2.63E-05 \\
\hline morphology of genital organ & 2.69E-05 & 2.94E-04 \\
\hline abnormal morphology of genital organ & 5.89E-05 & 4.13E-04 \\
\hline proliferation of embryoblast & $6.48 \mathrm{E}-05$ & 2.06E-04 \\
\hline fibrogenesis & 7.61E-05 & 1.15E-04 \\
\hline formation of embryonic tissue & $1.84 \mathrm{E}-03$ & $9.76 \mathrm{E}-06$ \\
\hline abnormal morphology of extraembryonic tissue & $6.59 \mathrm{E}-04$ & 2.79E-05 \\
\hline growth of embryo & 7.44E-03 & 3.30E-05 \\
\hline morphology of extraembryonic tissue & $1.23 \mathrm{E}-03$ & 3.69E-05 \\
\hline morphology of gonad & 1.16E-04 & 5.19E-05 \\
\hline
\end{tabular}

Selection of functional enrichment of diseases and disorders, molecular and cellular functions as well as physiological system development and function of all genes expressed in either fPGCs (9210) or oocytes (9207) using the IPA software. The complete IPA output, including p-values and the gene sets corresponding to each term, is available in Supplementary Table 4 ( $p<0.0001$ highlighted in red (fPGCs) or green (oocytes)). analysis we derived biological pathway, cellular component and molecular function Gene Ontology (GO) and KEGG pathway terms for subsets of genes solely expressed in either fPGCs (873) or oocytes (1141) or overlapping between fPGCs and oocytes (967). We considered terms with a p-value $<0.01$ to be significantly enriched.

Regarding genes solely expressed in fPGCs we found the KEGG pathways 'hsa04740:Olfactory transduction', 'hsa00140:Steroid hormone biosynthesis' and 'hsa00150:Androgen and estrogen metabolism' being significantly enriched. Concerning the GO terms we would like to emphasize the 'extracellular region' - terms for cellular component GO, 'sensory perception' connected terms for biological process GO and 'olfactory receptor activity' as highest enriched term for molecular function GO. These results indicate that within the genes exclusively expressed in fPGCs there is a significant association with olfactory-related processes and maybe function (Fig. 2A).

With respect to genes exclusively expressed in oocytes we found an association with the KEGG pathway 'hsa04810:Regulation of actin cytoskeleton' as enriched. Furthermore we found 'chromatin organization', 'cell cycle', 'transcription regulation' and 'endosomal' - associated biological property, cellular compartment and molecular function GO terms, respectively, thus indicative of transcriptional control as an active process in oocytes (Fig. 2C).

Regarding genes overlapping between fPGCs and oocytes we found, for example, the KEGG pathways 'hsa04510:Focal adhesion' and 'hsa04020:Calcium signaling pathway' as significant. Furthermore, we found molecular function GO terms associated with 'protein formation', 'chemokine receptor' and 'metal ion binding', cellular compartment GO terms associated with'(plasma-) membrane' and biological pathway GO terms associated with'metal ion transport', 'cell-cell-signaling' and 'secretion' (Fig. 2B).

\section{Ingenuity Systems canonical pathway analysis of all genes expressed in female PGCs and oocytes}

In order to acquire greater insights into pathways and functions associated with the total number of elevated transcript levels found in either fPGCs or oocytes, we conducted an IPA Ingenuity-based analysis. We compared transcription regulators, biological functions and canonical pathways most highly enriched in fPGCs and oocytes.

Regarding the canonical pathways output we found 'EIF2-', 'Regulation of elF4 and p70S6K-', 'mTOR-', 'ILK-', 'Ephrin Receptor-', 'Huntington's Disease-', 'Wnt/ $\beta$-catenin-' signaling pathways as well as 'Mitochondrial Dysfunction' being most enriched in both fPGCs and oocytes. Notable enrichment and ratio differences were observed in 'Aminoacyl-tRNA Biosynthesis', 'Cell Cycle Regulation by BTG Family', 'Role of CHK Proteins in Cell Cycle' and 'Role of BRCA1 in DNA Damage Response', which are more highly enriched in fPGCs. Whereas 'Germ Cell-Sertoli Cell Junction Signaling', 'Rac Signaling', 'CDK5 Signaling', 'Mitotic Roles of Polo-Like Kinase', 'Actin Cytoskeleton Signaling' and 'Ephrin B Signaling', are more highly enriched in oocytes (Table 1).

With respect to the output associated with biological function we found mammary-, colon- and colorectal tumor/cancer terms 
TABLE 3

\section{PUTATIVE CRUCIAL TRANSCRIPTION FACTORS ACTIVE IN FEMALE PGCs AND OOCYTES}

\begin{tabular}{lcc} 
Transcription Regulator & fPGCs & $\begin{array}{c}\text { Oocs } \\
\text { p-value }\end{array}$ \\
\hline HNF4A & p-value & $8.60 \mathrm{E}-18$ \\
MYCN & $1.78 \mathrm{E}-18$ & $1.59 \mathrm{E}-10$ \\
MYC & $3.94 \mathrm{E}-14$ & $4.10 \mathrm{E}-05$ \\
E2F4 & $3.77 \mathrm{E}-08$ & $1.08 \mathrm{E}-04$ \\
HTT & $7.48 \mathrm{E}-06$ & $9.06 \mathrm{E}-03$ \\
IRF4 & $6.05 \mathrm{E}-05$ & $>0,05$ \\
NFE2L2 & $1.17 \mathrm{E}-04$ & $8.49 \mathrm{E}-04$ \\
TP53 (includes EG:22059) & $1.88 \mathrm{E}-04$ & $7.81 \mathrm{E}-03$ \\
SREBF2 & $2.45 \mathrm{E}-04$ & $3.40 \mathrm{E}-03$ \\
HSF2 & $2.46 \mathrm{E}-04$ & $7.86 \mathrm{E}-03$ \\
XBP1 (includes EG:140614) & $4.29 \mathrm{E}-04$ & $1.92 \mathrm{E}-03$ \\
CCNE1 & $5.57 \mathrm{E}-04$ & $1.75 \mathrm{E}-03$ \\
E2F1 & $1.65 \mathrm{E}-03$ & $>0,05$ \\
TFEB & $2.12 \mathrm{E}-03$ & $4.82 \mathrm{E}-02$ \\
KDM5B & $2.14 \mathrm{E}-03$ & $5.00 \mathrm{E}-03$ \\
ATF4 & $2.41 \mathrm{E}-03$ & $>0,05$ \\
NOTCH4 & $2.60 \mathrm{E}-03$ & $>0.05$ \\
E2F3 & $2.81 \mathrm{E}-03$ & $8.90 \mathrm{E}-03$ \\
CTNNB1 & $3.92 \mathrm{E}-03$ & $1.00 \mathrm{E}-02$ \\
SREBF1 (includes EG:176574) & $4.39 \mathrm{E}-03$ & $>0.05$ \\
NPAS2 & $4.58 \mathrm{E}-03$ & $4.94 \mathrm{E}-03$ \\
ASCL2 & $4.77 \mathrm{E}-03$ & $4.94 \mathrm{E}-03$ \\
SOX11 & $4.77 \mathrm{E}-03$ & $4.82 \mathrm{E}-02$ \\
TBX2 & $6.92 \mathrm{E}-03$ & $2.03 \mathrm{E}-03$ \\
CDKN2A & $7.20 \mathrm{E}-03$ & $7.00 \mathrm{E}-04$ \\
PPARGC1B & $1.21 \mathrm{E}-02$ & $2.96 \mathrm{E}-02$ \\
TFAP2A & $1.21 \mathrm{E}-02$ & $2.84 \mathrm{E}-03$ \\
SKI & $1.56 \mathrm{E}-02$ & $>03$ \\
SPDEF & $1.57 \mathrm{E}-02$ & $>0.05$ \\
ELK3 & $2.62 \mathrm{E}-02$ & $6.27 \mathrm{E}-03$ \\
SKIL & $3.45 \mathrm{E}-02$ & $2.50 \mathrm{E}-04$ \\
HEXIM1 & $3.91 \mathrm{E}-02$ & $4.94 \mathrm{E}-03$ \\
SIRT2 & $4.30 \mathrm{E}-02$ & $4.70 \mathrm{E}-02$ \\
\hline & $4.53 \mathrm{E}-02$ & \\
\hline & & \\
\hline
\end{tabular}

Genes expressed in either fPGCs (9210) or oocytes (9207) were analysed to predict transcriptional regulators significant in the two gene expression datasets using the IPA software. Significant results are highlighted with decreasing colour gradients (fPGCs in red, oocytes in green) ranging from $p<0.0001$ over $p<0.001$ and $p<0.01$ to $p<0.05$

enriched in both of fPGCs and oocytes. 'Hematological neoplasia' and 'benign tumor' are slightly more enriched within fPGCs. The gene list associated with these cancer-related terms can be found in Supplementary Table 4. All of the 'Cell Cycle' terms are much more enriched in oocytes, furthermore we found 'binding of cells' and 'cell viability of tumor cell lines' being by far more enriched in fPGCs in contrast to 'cell death of tumor cell lines' which is enriched at a similar level in both fPGCs and oocytes. Concerning 'Development and Morphology' we found several 'embryonic tissue' related terms enriched in both cell types. The terms 'morphology of genital organ' and 'fibrogenesis' are slightly more enriched within fPGCs whereas 'formation of embryonic tissue', '(abnormal) morphology of extraembryonic tissue' and 'growth of embryo' are slightly more enriched within oocytes (Table 2). The list of genes associated with each of these terms can be found in Supplementary Table 4.

Regarding the transcription regulators output we found HNF4A, MYCN, MYC, E2F4 and HTT being the five most enriched transcription regulators in $\mathrm{PPGCs}$. Most of transcription regulators being enriched at a higher level show a smaller p-value for fPGCs than for oocytes (Table 3).

\section{Comparison of the transcriptomes of human and mouse female PGCs}

To further confirm independently the germ cells-specific transcriptome of our fPGCs we analysed the overlaps between our fPGCs with that of the transcriptomes of PGCs isolated from female mouse embryos at distinct stages of development (embryonic days 11.5, 12.5, 13.5, 14.5, 15.5, 16.5, 17.5, and 18.5) (Sabour et al., 2011). As shown in Fig. 3A, the highest overlap is between human fPGCs and 14.5F replicate (rep) 2 mouse fPGCs $(4269+635=$ 4904). However, Fig. $3 B$ highlights that the overlap between the intersection of 13.5F rep1 and 13.5F rep2 mouse fPGCs (which actually contains less but more conserved genes than each of $13.5 \mathrm{~F}$ replicate 1 and 2) and the human fPGCs contains more genes than all of the other overlaps of mouse fPGCs intersections and human fPGCs (4482). We identified 9210 genes being expressed in our human fPGCs (Fig. 1A). Of these, 6746 genes belong to the 8876 known orthologous genes mentioned above; therefore 6746 is the maximum number possible for the numbers in the lower parts of

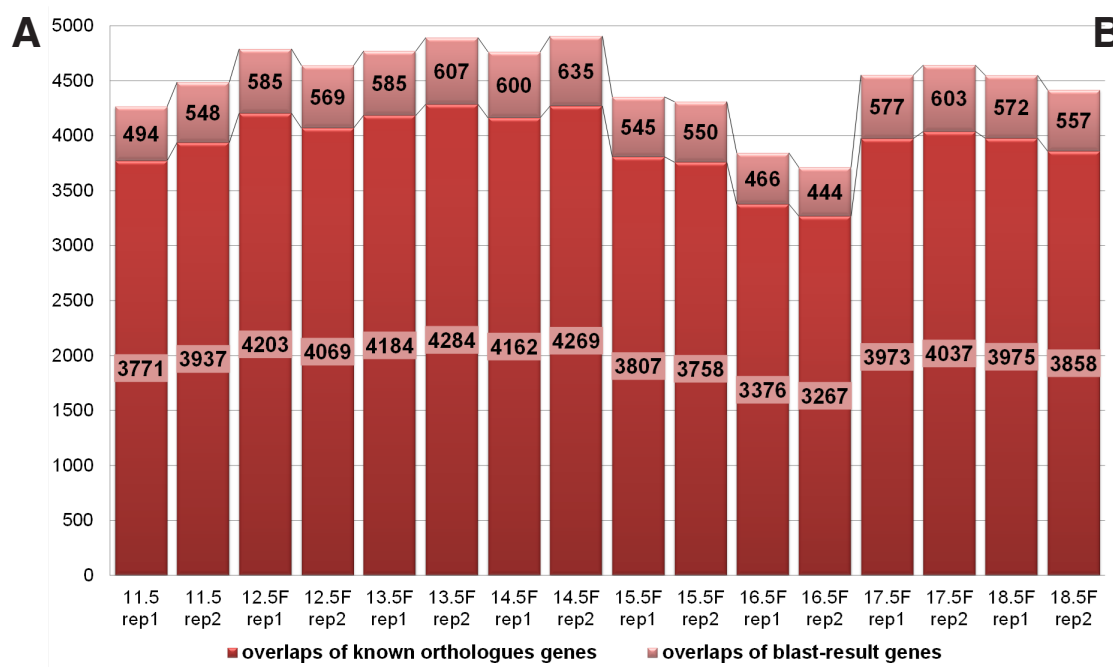

B 5000

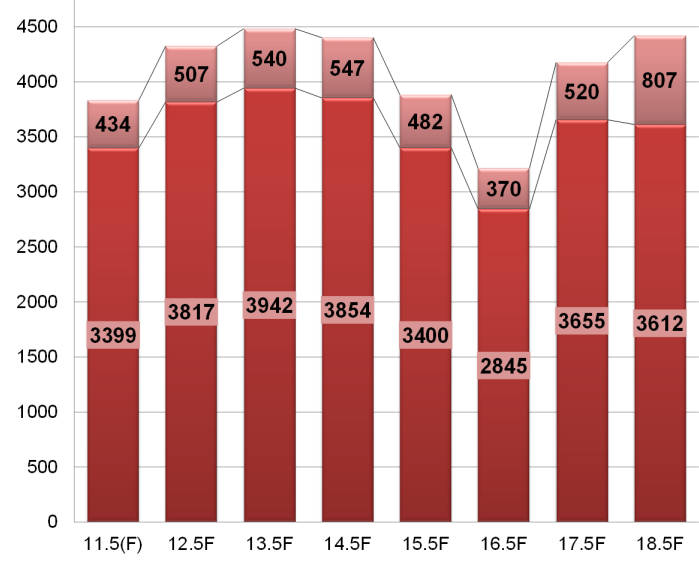

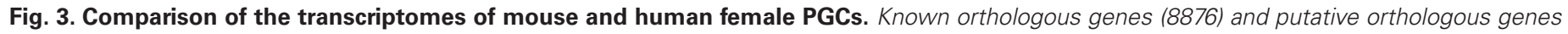

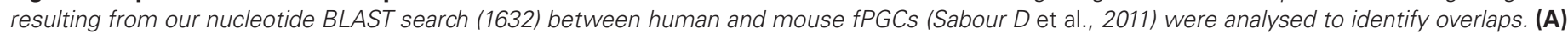

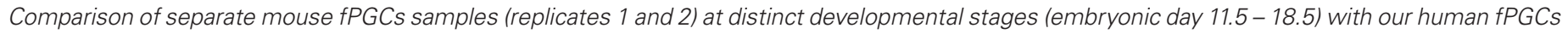
gene expression data set. (B) Comparison of the intersection of mouse fPGCs replicates 1 and 2 with our human fPGCs transcriptome data. 
TABLE 4

DISTINCT AND OVERLAPPING EXPRESSION OF MEMBERS OF THE OLFACTORY RECEPTOR GENE FAMILY IN FEMALE PGCS, MALE PGCS AND OOCYTES

\begin{tabular}{|c|c|c|c|c|c|}
\hline \multicolumn{6}{|c|}{ Olfactory receptors expressed in } \\
\hline fPGCs_mPGCs_Oocs & fPGCs & Oocs & mPGCs & fPGCs_Oocs & fPGCs_mPGCs \\
\hline OR10G7 & OR10AD1 & OR11A1 & OR10A7 & OR10R2 & OR5D13 \\
\hline OR10J1 & OR10G2 & OR1A2 & OR10V1 & OR13G1 & OR9I1 \\
\hline OR10S1 & OR11H4 & OR2A5 & OR1B1 & OR1D2 & \\
\hline OR10W1 & OR13A1 & OR4C11 & OR2A9P & OR1N1 & \\
\hline OR11G2 & OR1A1 & OR51A7 & OR2D3 & OR2AE1 & \\
\hline OR11H12 & OR1E2 & OR51B5 & OR2T6 & OR2L1P & \\
\hline OR12D2 & OR1L8 & OR51Q1 & OR4F15 & OR2M1P & \\
\hline OR13C2 & OR1N2 & OR52N4 & OR52W1 & OR2M2 & \\
\hline OR13C4 & OR2AT4 & OR5AK2 & OR5M11 & OR2M3 & \\
\hline OR13C9 & OR2T10 & OR5K4 & OR6A2 & OR3A1 & \\
\hline OR14l1 & OR2T12 & OR5M3 & OR6C76 & OR4C12 & \\
\hline OR1J2 & OR4C15 & OR7D4 & OR6K6 & OR4F4 & \\
\hline OR1J4 & OR4C3 & OR8A1 & OR7E37P & OR4N2 & \\
\hline OR2A1 & OR4D11 & OR8B2 & & OR4S1 & \\
\hline OR2A2 & OR4D2 & OR8B4 & & OR5112 & \\
\hline OR2A20P & OR4D9 & ORC1 & & OR5W2 & \\
\hline OR2A25 & OR4K14 & & & OR6C65 & \\
\hline OR2AG1 & OR4K17 & & & OR6C74 & \\
\hline OR2B2 & OR4K2 & & & OR7C2 & \\
\hline OR2C3 & OR4S2 & & & OR7G3 & \\
\hline OR2G3 & OR4X1 & & & OR8G1 & \\
\hline OR2L3 & OR51L1 & & & OR8G5 & \\
\hline OR2M4 & OR52L1 & & & OR8K1 & \\
\hline OR2T11 & OR52N5 & & & OR8K3 & \\
\hline OR2T33 & OR56A3 & & & OR8U9 & \\
\hline OR2W3 & OR56B1 & & & & \\
\hline OR2W5 & OR5AR1 & & & & \\
\hline OR2Z1 & OR5AS1 & & & & \\
\hline OR4A15 & OR5H2 & & & & \\
\hline OR4B1 & OR5H6 & & & & \\
\hline OR4C45 & OR5K1 & & & & \\
\hline OR4C46 & OR6W1P & & & & \\
\hline OR4F3 & OR6X1 & & & & \\
\hline OR51D1 & OR8U8 & & & & \\
\hline OR51E2 & OR9G1 & & & & \\
\hline OR51M1 & ORC4 & & & & \\
\hline
\end{tabular}

OR52B2

OR52B6

OR52E6

OR52B6

OR52E6

OR52H1

OR52J3

OR52K1

OR52N2

OR56B4

OR5AN1

OR5AU1

OR5C1

OR5K2

OR5R1

OR5T1

OR5V1

OR6B3

OR6C6

OR6F1

OR6V1

OR7A10

OR7A17

OR7E156P

OR7G1

OR8D1

OR8G2

$\mathrm{OR} 8 \mathrm{H} 3$

OR8J3

ORAOV 1

ORC3

ORC6

ORM1

ORMDL2

ORMDL3

Genes highlighted in red are those with orthologs in mouse PGCs. Also refer to Supplementary Table 5. the columns in Fig. 3. For 1242 of the fPGCs genes, we found a possible orthologous gene by nucleotide BLASTN and as such 1242 is the maximum number possible for the numbers in the upper parts of the columns in Fig. 3. Novel orthologous genes either human or mouse are highlighted in blue in Supplementary Table 5.

As a result there are $1242 \mathrm{fPGCs}$ genes remaining which are not comparable to any of the mouse genes detectable using the mouse Illumina BeadChip neither by official gene symbol nor our BLASTN result. We identified 4904 genes for the fPGCs-14.5F rep2 overlap and 4482 for the 13.5F rep1/rep2-intersection - fPGCs overlap of a maximum of $6746+1222=7968$ genes.

\section{Distinct and overlapping expression of members of the olfac- tory receptor gene family}

Olfactory receptor (OR) proteins are members of a large family of G-protein-coupled receptors (GPCR) arising from single exon-coding genes and are the largest in the genome (Feldmesser et al., 2006). In an earlier study, we identified expression of OR-encoding genes expressed in mPGCs (Goto et al., 1999), to further validate this finding, we interrogated our current dataset for the presence of these genes. In total, we detected expression of 164 OR-encoding genes. Of these 72 are common between fPGCs, mPGCs and oocytes, 36 in fPGCs, 16 in oocytes, 13 in mPGCs, 25 in both fPGCs and oocytes and finally 2 in common between fPGCs and mPGCs. Of these human OR-encoding genes, we identified 33 mouse orthologs highlighted in red (Table 4).

\section{Discussion}

To date the in vivo derived transcriptomes of both male and female PGCs have been restricted to the mouse, where the identification and isolation of such cells is feasible using the promoter sequences of PGCs-lineage markers such as Oct4, Blimp1 and Prdm14 serving as reporters (Sabour et al., 2011; Saitou, 2009). To circumvent this drawback, in vitro differentiation models both human and mouse (Hubner et al., 2003; Toyooka et al., 2003; Geijsen et al., 2004; Kee et al., 2006; Nagano, 2007; Qing et al., 2007; Wei et al., 2008; Hayashi et al., 2011; Panula etal., 2011) have been established using pluripotent stem cells based on embryonic and induced pluripotent stem cells. Although differentiation of human ESCs and iPSCs into PGCs-like cells have been performed in mouse (Geijsen et al., 2004; Kee et al., 2006; Panula et al., 2011) transcriptome analysis of the derived PGCs have been restricted to known PGCs-specific genes such as BLIMP1/PRDM1, c-KITSTELLA/DPPA3, VASA/DDX4, and FRAGILIS/IFITM5. The lack of genome-wide transcriptome analyses of these human ESCs- and iPSCs-derived PGCs further precludes in-depth knowledge and analyses of key mechanisms underlying the complex and intricate biological processes of human germ cell development and subsequent gametogenesis.

In an attempt to overcome some of the afore-mentioned shortfalls associated with current in vitro models of human PGCs, we have carried out in this study extensive transcriptome-based comparative analyses of the molecular portraits of SMART-generated T7 promoter-linked double-stranded cDNA samples derived from 4 unfertilized oocytes, 200 mPGCs and 500 fPGCs previously generated as described in (Adjaye et al., 1999; Goto et al., 1999). To enrich for transcripts expressed in female germ cells, we included mPGCs as a means of excluding Y-linked genes. Confirmation of the success of this subtraction approach is the detected expression 
of $Z F Y$ solely in mPGCs and the Zona Pellucida genes $Z P 4$ in both fPGCs and oocytes, whilst ZP1 and ZP3 were detected in oocytes only (Supplementary Table 1).

Amongst the well characterised PGCs-specific genes, we detected for example, expression of BLIMP1/PRDM1 and PIWIL2 solely in the fPGCs and mPGCs cells, VASA/DDX4 in fPGCs and oocytes, $D A Z L$ and STELLA/DPPA3 in the oocytes only (Supplementary Table 1). Interestingly, LIN28A is expressed in all cell types and it has been shown in the mouse that Lin28, a negative regulator of Let-7, is essential for PGCs development and also associated with germ cell malignancy (Rybak et al., 2008; West et al., 2009).

BMP signaling has been shown to be essential for PGCs specification (Ying et al., 2000; Ying and Zhao, 2001; Pesce et al., 2002) and in line with this we detected expression of BMP2, 3, 4, 6, 7 and GDF1, 2, 3, 9 and 15 and the receptors BMPR1A and BMPR2 (Supplementary Table 1).

The observed variable expression patterns, for example, VASA/ $D D X 4$ in fPGCs and oocytes, DAZL and STELLA/DPPA3 in the oocytes can be attributed to the PCR-based SMART-generated T7 promoter-linked double-stranded cDNA from the reduced cell numbers (4 unfertilized oocytes, 200 mPGCs and 500 fPGCs). Nonetheless, our approach has provided for the first time a snapshot of the transcriptomes of these rare human cells.

The comparison of the human fPGCs transcriptomes with the transcriptomes of PGCs isolated from mouse embryos at distinct stages (E11.5-E18.5) of development (Sabour et al., 2011) resulted in the identification of 1632 mouse orthologous genes with nucleotide identities within the coding regions ranging from $100-22 \%$. The highest number of overlapping genes was with the transcriptomes derived from E14.5 mice (Fig. 3), the significance of this is at present unknown. Furthermore, of the 11 genes identified by Sabour et al., as expressed exclusively in male and female PGCs both in vitroand in vivo but not in ESCs, we identified 4 of these (4930432K21Rik, Mov10l1, Tex13, Hba-a1) as expressed in human fPGCs, thus further confirming the quality of our dataset which highlights the conservation of key PGCs-associated genes potentially involved in the development and specification of PGCs in both species.

With the transcriptome data at hand we could associate expressed genes to signaling pathways. For example, we identified key signaling pathways such as mTOR, WNT/ $\beta$-catenin, ERK/MAPK, PI3K/AKT, estrogen receptor and androgen receptor, cell cycle regulation by BTG family proteins, Rac, CDK5, Actin cytoskeleton, Ephrin B and germ cell-Sertoli cell junction signaling as active in fPGCs and oocytes.

Cytological analysis in mice and human suggests that both female and male PGCs are equally capable of entering meiosis (12 dpc in mice and 10 weeks in humans) and that the decision of cell fate of germ cells, either meiosis or mitosis takes place in the gonad (McLaren and Southee, 1997; Suzuki and Saga, 2008; Bowles and Koopman, 2010). It is still unknown and controversial whether entry into meiosis is induced in the female gonad or whether it is intrinsically programmed in both male and female PGCs and inhibited in the male gonad and permissive in the female gonad, or whether it is due to a combination of regulatory factors. Indeed, we do see differential expression of a host of transcription factors (for example, zinc finger containing transcription factors-ZNFs) in fPGCs and mPGCs, as potential regulators of this decision making process (Supplementary Table 1).

Furthermore, expression of several genes associated with components of the meiotic machinery was observed, for example, the synaptonemal complex (SYCP2, SYCP3, TEX11, TEX13B, TEX15), meiosis-specific cohesins (SMC1B, STAG3), meiotic recombination machinery (DMC1, MSH4, TRIP13), piRNA pathway (PIWIL2, $T D R D 1, M A E L)$ and other meiosis-associated genes (HSPA4L, HSF2BP, HORMAD2, INTS6, CREBL2, ATF7IP2, MTL5, ZFP473) (Su et al., 2011). In contrast, in mPGCs we detected expression of NODAL, which has been shown in the mouse to have an autocrine signaling role during the specification of male PGCs (Souquet et al., 2012).

An unexpected observation in our study is the expression of a plethora of olfactory receptor-encoding genes in fPGCs, mPGCs and unfertilized oocytes (Table 4). Olfactory receptors (ORs) which are G-protein-coupled receptors (GPCR) share a 7-transmembrane domain structure with many neurotransmitter and hormone receptors and are responsible for the recognition and $G$ protein-mediated transduction of odorant signals. In an earlier study using the same fPGCs and mPGCs mRNAs (differential display based-analyses) as employed in this study, we identified OR-encoding genes expressed in mPGCs cells (Goto et al., 1999). Although OR-encoding genes have so far been detected in MPGCs, the detected expression in fPGCs and oocytes in the current study is not an artefact as it has recently been shown that there is widespread expression of olfactoryrelated genes in tissues as diverse as testis, muscle, liver and skin, although some of these might be pseudogenes (Feldmesser et al., 2006). Of the 164 expressed OR-encoding genes, OR10J1, OR11A1, OR1D2, OR52K1 and OR7A17 have been detected as expressed in human testis (Feldmesser et al., 2006) and of these only OR10J1 has so far been detected as expressed in mPGCs (Parmentier et al., 1992). Additionally, of the 164 human OR-encoding genes differentially expressed between mPGCs, fPGCs and oocytes, we have identified 33 mouse orthologs (for example, OR51M1/Olfr78, OR4D11/Olfr1423 and OR1B1/Olfr362) highlighted in red (Table 4). Though unexpected, this is the first description of a plethora of OR-encoding genes showing overlapping and distinct expression patterns in human unfertilized oocytes, male and female PGCs at 10 weeks of gestation. Based on our findings, the current hypothesis that OR-encoding genes are involved in sperm chemotaxis should be extended to include the development of female germ cells and oocytes.

In summary, we anticipate that our current dataset will provide insights into the design of more extensive functional studies that might increase our meagre knowledge of the genes and associated signaling pathways operative during germ cell development and hence in turn lead to the development of strategies enabling better differentiation and molecular characterisation of germ cells derived from either ESCs or iPSCs. Ultimately, this would have a profound relevance to reproductive as well as regenerative medicine.

\section{Materials and Methods}

The isolation of the human germ cells and also failed fertilised oocytes are as described in detail in Goto et al., 1999 and Adjaye et al., 1999 respectively.

\section{Fetal samples}

The human fetal samples were obtained from the Human Embryonic Tissue Bank maintained at the Institute of Child Health $(\mathrm{ICH})$ in collaboration with the Department of Obstetrics and Gynaecology, University College London (UCL), UK, and funded by the Medical Research Council. The collection, deposition and use of human fetal samples were approved by the Joint UCL/UCLH Committees on the Ethics of Human Research and 
the Ethical Committee of the $\mathrm{ICH}$, and were carried out in accordance with the Polkinghorne report. Gonads were obtained from a male and a female fetus, at 10 weeks gestation, for isolation of PGCs. The age of the fetus was the anatomical (embryonic) age, as determined by limb development, and not the age from the last menstrual period (LMP). The fetal samples were kept on ice in Leibovitz's L15 medium (Gibco BRL, UK) and the gonads were dissected from the fetuses within 2-3 h after the surgical termination of pregnancy.

\section{Isolation of germ cells from the gonad}

Germ cells were isolated from the gonad following the protocols described by Buehr and McLaren, 1993. The gonads, dissected from the fetus, were freed from the attached mesonephric tissue under the dissecting microscope. They were then incubated in $1 \mathrm{mmol} / \mathrm{EDTA}$ in $\mathrm{Ca}^{2+}$ - and $\mathrm{Mg}^{2+}$-free phosphate-buffered saline (PBS) for $5 \mathrm{~min}$ at room temperature to loosen the germ cells from somatic cells. The gonads were washed briefly in PBS, transferred to fresh PBS and gently squeezed by watchmaker's forceps to release the germ cells. The germ cells could be distinguished from somatic cells by their size, round shape and bright appearance. The germ cells were manually collected by a finely-drawn Pasteur pipette, and 200 (male) and 500 (female) germ cells placed in $30 \mu \mathrm{l}$ of ice-cold lysis buffer [0.8\% IGEPAL (Sigma, UK), $1 \mathrm{U}$ of RNase inhibitor (Gibco BRL, UK), $5 \mathrm{mM}$ dithiothreitol (DTT; Gibco BRL)], snap-frozen in liquid nitrogen and stored at $-70^{\circ} \mathrm{C}$ until RNA extraction.

\section{Oocyte samples}

Human oocytes derived by in vitro fertilization (IVF), and forming part of a research project on embryo culture conducted by V. Bolton, were donated for research with consent by patients attending the Assisted Conception Unit, King's College Hospital (KCH) London. Pituitary suppression, ovarian stimulation and oocyte retrievals were carried out as described previously (Waterstone and Parsons, 1992). IVF was performed as described previously (Bolton et al., 1989) except that the culture medium used was a commercial preparation of Earle's balanced salt solution (Medi-Cult, Imperial Laboratories, Hampshire, UK). The four unfertilized oocytes collected on day 1 , were failed-fertilization oocytes selected from cohorts placed with poor quality sperm such that none of the oocytes developed a second pronucleus. Great care was taken to remove contaminating cumulus cells surrounding the oocytes. The oocytes were anonymized and lysed at $\mathrm{KCH}$ before transfer to the Institute of Child Health. Oocytes in $0.5 \mu \mathrm{l}$ of PBS were added to $1.5 \mu$ l of lysis buffer [0.8\% IGEPAL (Sigma), $1 \mathrm{U} / \mu$ l of RNA$\sin$ (Gibco BRL), $5 \mathrm{mM}$ DTT (Gibco BRL)], centrifuged briefly at $12000 \times \mathrm{g}$ and overlayed with one drop of mineral oil (Sigma) and stored at $-70^{\circ} \mathrm{C}$.

\section{mRNA extraction and cDNA amplification}

T7 promoter-linked double-stranded cDNA samples derived from 4 unfertilized oocytes, $200 \mathrm{mPGCs}$ and $500 \mathrm{fPGCs}$ were previously generated as described (Adjaye et al., 1999; Goto et al., 1999; Adjaye et al., 2005). Briefly, mRNAwas extracted from thawed lysed cells using Oligo-dT magnetic beads (Dynabeads). cDNA was generated using T7 promoter-linked oligodT primers for the reverse transcription (RT) step, and whole-transcriptome amplification was executed using a modified SMART amplification protocol (BD Biosciences, San Jose, CA, http://www.bdbiosciences. com). Finally, concentrations were evaluated on the Agilent 2100 Bioanalyzer.

\section{IIlumina bead chip hybridization and data analyses}

Global gene expression analysis was carried out employing the IIlumina microarray platform. SMART generated T7 promoter-linked cDNA were used as input for the T7 polymerase-mediated in vitro transcription to produce biotin-labeled cRNA (Illumina TotalPrep RNA Amplification Kit, Ambion, Austin, TX, USA). 500 ng of purified cRNA was hybridized onto Illumina HumanRef-8 v3 Expression BeadChips (Illumina, San Diego, CA, USA) on the Illumina Beadstation 500 platform followed by washing and blocking of the samples, staining with streptavidin-Cy3 and quantitative detection of the resulting fluorescent array image.
Raw data were obtained using the manufacturer's software GenomeStudio V2010.2 (Gene Expression module v.1.7.0). Subsequently, raw data were imported into the Bioconductor environment (Gentleman et al., 2004) and quantile normalized using the beadarray package (Dunning et al., 2007). In order to test for global gene expression similarities, pairwise Pearson correlation coefficients were calculated for all samples. Pearson correlation co-efficients, scatter- and boxplots, and hierarchical clustering were calculated using the R environment (http://www.r-project.org). We examined the distribution of normalized gene expression signals in each sample separately. Due to the low overall signal intensities we defined the quantile of 0.5 (arbitrary selection) as a threshold for identifying genes showing elevated expression levels in order to define these as "expressed" (Supplementary Fig. 1 for the distribution of raw and normalized gene expression signals). To identify overlapping and distinct genes expressed within oocytes, male and female PGCs we generated Venn Diagrams using the 'VENNY' online tool (http://bioinfogp.cnb.csic.es/tools/venny/ index.html). Functional annotation and enrichment analyses of particular gene sets resulting from the Venn Diagram analysis were performed using the DAVID platform version 6.7 (http://david.abcc.ncifcrf.gov/home.jsp) (Dennis et al., 2003; Huang da et al., 2009). Human official gene symbols were used as input against DAVID's 'homo sapiens' background; analyses were executed based on DAVID default parameter settings unless stated otherwise. We further analysed the data employing IPA (Ingenuity Systems, www.ingenuity.com) to gain further information on potential important transcription factors and alternative surveys on enriched biological functions and canonical pathways. For each sample of interest we used official gene symbols of the total number of expressed genes to do the IPA analysis based on the entire active cellular transcriptome.

Finally, we performed a nucleotide blast (Perl version 5.12.4-4, 201109-06, www.perl.org; Bioperl version 1.6.901-1, 2011-06-17, www.bioperl. org; BLAST (Altschul et al., 1990)) between genes we found expressed in human FPGCs and within one of several datasets of mouse fPGCs derived from mouse embryos at distinct stages of gestation (Sabour et al., 2011). We compared the non-redundant union of all human genes expressed in either fPGCs, mPGCs and oocytes, amounting to 12165 genes, to the non-redundant list of all mouse genes detectable as expressed by the Illumina MouseRef-8 v2.0 expression BeadChip used by Sabour D. et al., which is a total of 17957 genes. This analysis led to the identification of 8876 known orthologous genes bearing the same official gene symbols. The remaining $(12165-8876=) 3289$ human genes were used to perform a nucleotide blast search against the remaining (17957- $8876=$ =) 9081 mouse genes to identify additional matching genes. Applying an arbitrary expectation value threshold of $1 \mathrm{E}-10$ resulted in the identification of 1632 pairs of human and mouse genes showing significant sequence overlap and are thus also declared as orthologous genes (see Supplementary Table 5).

\section{Acknowledgements}

We thank $A$. Sabah at the microarray facility for her excellent support. This work was in part funded by the BMBF (Grant numbers FKZ0315398G and 01GN1005) and the ERASysBio+ initiative [BMBF; grant number 0315717A], supported under the EU ERA-NET Plus scheme in FP7.

\section{References}

ADJAYE J., BOLTON V. and MONK M. (1999). Developmental expression of specific genes detected in high-quality cdna libraries from single human preimplantation embryos. Gene, 237: 373-383.

ADJAYE J., HUNTRISS J., HERWIG R., BENKAHLA A., BRINK T. C., WIERLING C., HULTSCHIG C., GROTH D., YASPO M. L., PICTON H. M., GOSDEN R. G. and LEHRACH H. (2005). Primary differentiation in the human blastocyst: Comparative molecular portraits of inner cell mass and trophectoderm cells. Stem cells, 23: 1514-1525.

ADJAYEJ. and MONKM. (2000). Transcription of homeobox-containing genes detected in cdna libraries derived from human unfertilized oocytes and preimplantation embryos. Molecular Hum Reprod 6: 707-711. 
ALTSCHUL S. F., GISH W., MILLER W., MYERS E. W. and LIPMAN D. J. (1990). Basic local alignment search tool. J. Molec. Biol. 215: 403-410.

ANDERSON R., COPELANDT. K., SCHOLERH., HEASMAN J. and WYLIE C. (2000). The onset of germ cell migration in the mouse embryo. Mech. Dev. 91: 61-68.

BOLTON V. N., HAWES S. M., TAYLORC. T. and PARSONS J. H. (1989). Development of spare human preimplantation embryos in vitro: An analysis of the correlations among gross morphology, cleavage rates, and development to the blastocyst. $J$ In vitro Fert Embryo Transf, 6: 30-35.

BOWLES J. and KOOPMAN P. (2010). Sex determination in mammalian germ cells: Extrinsic versus intrinsic factors. Reproduction, 139: 943-958.

BUEHR M. and MCLAREN A. (1993). Isolation and culture of primordial germ cells. Methods Enzymol, 225: 58-77.

DENNIS G., JR., SHERMAN B. T., HOSACK D. A., YANG J., GAO W., LANE H. C. and LEMPICKI R. A. (2003). David: Database for annotation, visualization, and integrated discovery. Genome Biol, 4: P3.

DONOVAN P. J. and DE MIGUEL M. P. (2003). Turning germ cells into stem cells. Curr. Opin. Genet. Dev. 13: 463-471.

DUNNING M. J., SMITH M. L., RITCHIE M. E. and TAVARE S. (2007). Beadarray: R classes and methods for illumina bead-based data. Bioinformatics, 23:2183-2184.

EWING M. W., LIU S. C., GNARRA J. R., WALTHER M. M., MEYERS C. E. and LINEHAN W. M. (1993). Effect of suramin on the mitogenic response of the human prostate carcinoma cell line pc-3. Cancer, 71(3 Suppl): 1151-1158.

FELDMESSER E., OLENDER T., KHEN M., YANAI I., OPHIR R. and LANCET D. (2006). Widespread ectopic expression of olfactory receptor genes. BMC Genomics, 7: 121.

GEIJSEN N., HOROSCHAK M., KIM K., GRIBNAU J., EGGAN K. and DALEY G. Q. (2004). Derivation of embryonic germ cells and male gametes from embryonic stem cells. Nature, 427: 148-154.

GENTLEMAN R. C., CAREY V. J., BATES D. M., BOLSTAD B., DETTLING M., DUDOIT S., ELLIS B., GAUTIER L., GE Y., GENTRY J., HORNIK K., HOTHORN T., HUBER W., IACUS S., IRIZARRY R., LEISCH F., LI C., MAECHLER M., ROSSINI A. J., SAWITZKI G., SMITH C., SMYTH G., TIERNEY L., YANG J. Y. and ZHANG J. (2004). Bioconductor: Open software development for computational biology and bioinformatics. Genome Biol, 5: R80.

GINSBURG M., SNOW M. H. and MCLAREN A. (1990). Primordial germ cells in the mouse embryo during gastrulation. Development, 110: 521-528.

GONDOS B. and HOBEL C. J. (1971). Ultrastructure of germ cell development in the human fetal testis. Z Zellforsch Mikrosk Anat, 119: 1-20.

GOTO T., ADJAYE J., RODECK C. H. and MONK M. (1999). Identification of genes expressed in human primordial germ cells at the time of entry of the female germ line into meiosis. Molecular Hum. Reprod. 5: 851-860.

HAYASHI K., OHTA H., KURIMOTO K., ARAMAKI S. and SAITOU M. (2011). Reconstitution of the mouse germ cell specification pathway in culture by pluripotent stem cells. Cell, 146: 519-532.

HUANG DA W., SHERMAN B. T. and LEMPICKI R. A. (2009). Systematic and integrative analysis of large gene lists using david bioinformatics resources. Nat Protoc, 4: 44-57.

HUBNER K., FUHRMANN G., CHRISTENSON L. K., KEHLER J., REINBOLD R., DE LA FUENTE R., WOOD J., STRAUSS J. F., 3RD, BOIANI M. and SCHOLER H. R. (2003). Derivation of oocytes from mouse embryonic stem cells. Science, 300: 1251-1256.

KEE K., GONSALVES J. M., CLARK A. T. and PERA R. A. (2006). Bone morphogenetic proteins induce germ cell differentiation from human embryonic stem cells. Stem Cell Dev. 15: 831-837.

LOOIJENGAL. H. (2009). [advances in basic research on testicular germ cell tumors: Clinical implications]. Urologe A, 48: 350-358.

MCLAREN A. and SOUTHEE D. (1997). Entry of mouse embryonic germ cells into meiosis. Dev. Biol. 187: 107-113.

MOLYNEAUX K. A., STALLOCK J., SCHAIBLE K. and WYLIE C. (2001). Time-lapse analysis of living mouse germ cell migration. Dev. Biol. 240: 488-498.

MOTTA P. M. and MAKABE S. (1986). Germ cells in the ovarian surface during fetal development in humans. A three-dimensional microanatomical study by scanning and transmission electron microscopy. J. Submicros. Cytol. 18: 271-290.

NAGANO M. C. (2007). In vitrogamete derivation from pluripotent stem cells: Progress and perspective. Biol Reprod, 76: 546-551.

OOSTERHUIS J. W. and LOOIJENGA L. H. (2005). Testicular germ-cell tumours in a broader perspective. Nature Rev. Cancer, 5: 210-222.

PANULA S., MEDRANO J. V., KEE K., BERGSTROM R., NGUYEN H. N., BYERS B., WILSON K. D., WU J. C., SIMON C., HOVATTA O. and REIJO PERA R. A. (2011). Human germ cell differentiation from fetal- and adult-derived induced pluripotent stem cells. Human Molec. Genet. 20: 752-762.

PARMENTIER M., LIBERT F., SCHURMANS S., SCHIFFMANN S., LEFORT A., EGGERICKX D., LEDENT C., MOLLEREAU C., GERARD C., PERRET J. and et al., (1992). Expression of members of the putative olfactory receptor gene family in mammalian germ cells. Nature, 355: 453-455.

PESCE M., GIOIA KLINGER F. and DE FELICI M. (2002). Derivation in culture of primordial germ cells from cells of the mouse epiblast: Phenotypic induction and growth control by bmp4 signalling. Mech. Dev. 112: 15-24.

QING T., SHI Y., QIN H., YE X., WEI W., LIU H., DING M. and DENG H. (2007). Induction of oocyte-like cells from mouse embryonic stem cells by co-culture with ovarian granulosa cells. Differentiation, 75: 902-911.

RYBAK A., FUCHS H., SMIRNOVA L., BRANDT C., POHL E. E., NITSCH R. and WULCZYN F. G. (2008). A feedback loop comprising lin-28 and let-7 controls prelet-7 maturation during neural stem-cell commitment. Nat Cell Biol, 10: 987-993.

SABOUR D., ARAUZO-BRAVO M. J., HUBNER K., KO K., GREBER B., GENTILE L., STEHLING M. and SCHOLER H. R. (2011). Identification of genes specific to mouse primordial germ cells through dynamic global gene expression. Human Molec. Genet. 20: 115-125.

SAITOU M. (2009). Specification of the germ cell lineage in mice. Front Biosci, 14: 1068-1087.

SAITOU M., BARTON S. C. and SURANI M. A. (2002). A molecular programme for the specification of germ cell fate in mice. Nature 418: 293-300.

SOUQUET B., TOURPIN S., MESSIAEN S., MOISON D., HABERT R. and LIVERA G. (2012). Nodal signaling regulates the entry into meiosis in fetal germ cells. Endocrinology, 153: 2466-2473.

SU Y., LI Y. and YE P. (2011). Mammalian meiosis is more conserved by sex than by species: Conserved co-expression networks of meiotic prophase. Reproduction, 142: 675-687.

SUZUKI A. and SAGA Y. (2008). Nanos2 suppresses meiosis and promotes male germ cell differentiation. Genes Dev, 22: 430-435.

TOYOOKA Y., TSUNEKAWA N., AKASU R. and NOCE T. (2003). Embryonic stem cells can form germ cells in vitro. Proc. Natl. Acad. Sci. USA 100: 11457-11462.

WATERSTONE J. J. and PARSONS J. H. (1992). A prospective study to investigate the value of flushing follicles during transvaginal ultrasound-directed follicle aspiration. Fertil Steril, 57: 221-223.

WEI W., QING T., YE X., LIU H., ZHANG D., YANG W. and DENG H. (2008). Primordial germ cell specification from embryonic stem cells. PLoS One, 3: e4013.

WEST J. A., VISWANATHAN S. R., YABUUCHIA., CUNNIFFK., TAKEUCHIA., PARK I. H., SERO J. E., ZHU H., PEREZ-ATAYDE A., FRAZIER A. L., SURANI M. A. and DALEY G. Q. (2009). A role for lin28 in primordial germ-cell development and germ-cell malignancy. Nature, 460: 909-913.

WESTERN P., MALDONADO-SALDIVIA J., VAN DEN BERGEN J., HAJKOVA P., SAITOU M., BARTON S. and SURANI M. A. (2005). Analysis of esg1 expression in pluripotent cells and the germline reveals similarities with oct4 and sox 2 and differences between human pluripotent cell lines. Stem cells, 23: 1436-1442.

WITSCHI E. (1946). Early history of the human germ cells. Anatomical Rec. 94: 506.

YING Y., LIU X. M., MARBLE A., LAWSON K. A. and ZHAO G. Q. (2000). Requirement of bmp8b for the generation of primordial germ cells in the mouse. Mol Endocrinol, 14: 1053-1063.

YING Y. and ZHAO G. Q. (2001). Cooperation of endoderm-derived bmp2 and extraembryonic ectoderm-derived bmp4 in primordial germ cell generation in the mouse. Dev. Biol. 232: 484-492. 


\section{Further Related Reading, published previously in the Int. J. Dev. Biol.}

The Dr-nanos gene is essential for germ cell specification in the planarian Dugesia ryukyuensis Haruka Nakagawa, Hirotsugu Ishizu, Ayako Chinone, Kazuya Kobayashi and Midori Matsumoto Int. J. Dev. Biol. (2012) 56: 165-171

A polymorphic, thrombospondin domain-containing lectin is an oocyte marker in Hydractinia: implications for germ cell specification and sex determination Brahim Mali, R. Cathriona Millane, Günter Plickert, Marcus Frohme and Uri Frank Int. J. Dev. Biol. (2011) 55: 103-108

In vitro germ cell differentiation during sex differentiation in a teleost fish Tohru Kobayashi Int. J. Dev. Biol. (2010) 54: 105-111

Differentiation of mouse primordial germ cells into female or male germ cells N Nakatsuji and S Chuma

Int. J. Dev. Biol. (2001) 45: 541-548

The meiotic specific synaptonemal complex protein SCP3 is expressed by female and male primordial germ cells of the mouse embryo A D Di Carlo, G Travia and M De Felici Int. J. Dev. Biol. (2000) 44: 241-244

5 yr ISI Impact Factor $(2011)=2.959$

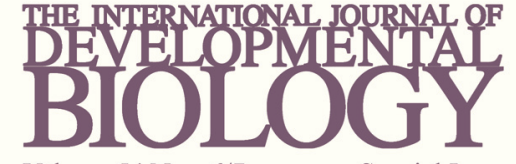

Volume 54 Nos. 6/7
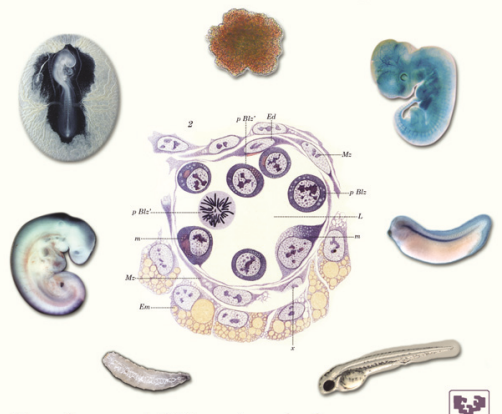

Developmental Hematopoiesis

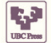

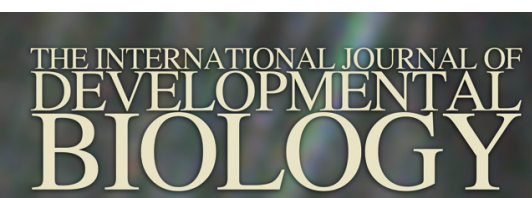

Special Issue

Volume 56 Nos. 1/2/3

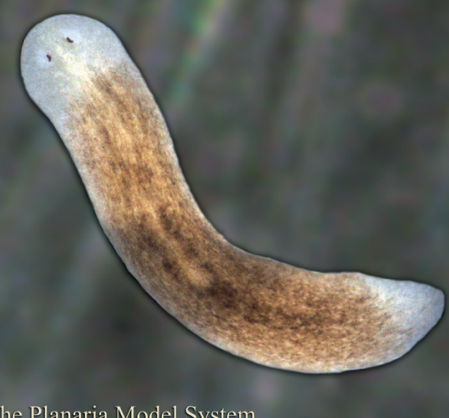

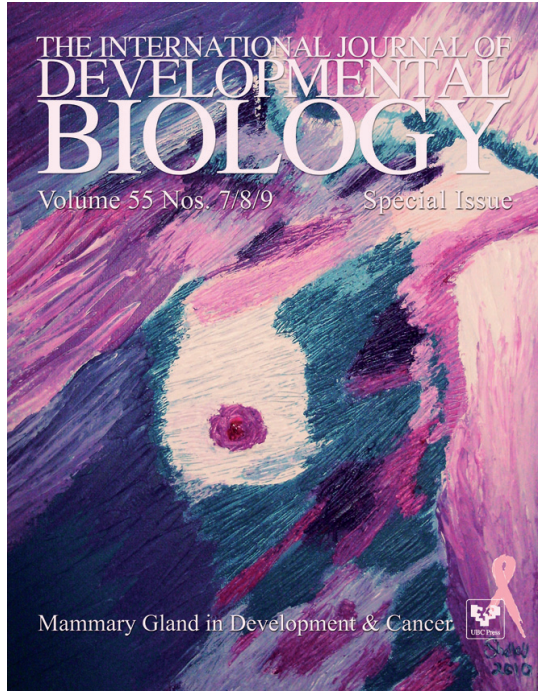

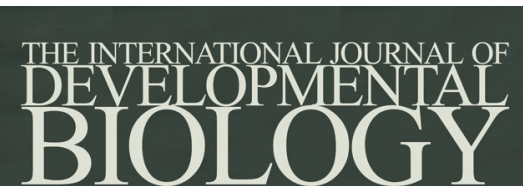

Volume 55 Nos. $4 / 5$

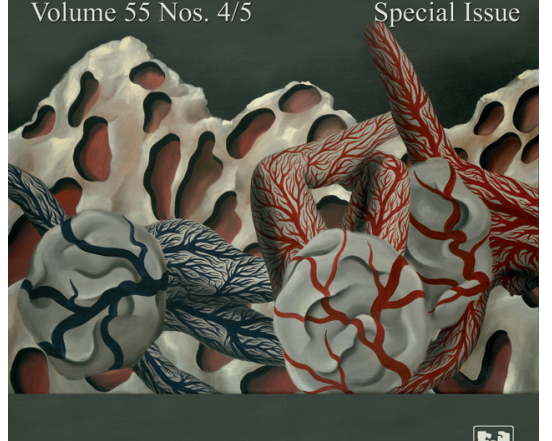

Angiogenesis in Development \& Cancer 